\title{
EXPENSE EVALUATION AND OPTIMIZATION FOR PROVIDING COMMUNICATION SYSTEM SUSTAINABILITY
}

DOI: $10.36724 / 2072-8735-2020-\mid 4-7-57-63$

Filatov Vladimir Ivanovich, Moscow State Technical University, Moscow, Russia, vfillo@mail.ru

Khokhlachev Yevgeny Nikolaevich, Military Academy of RVSN named after Peter the Great, Balashikha, Russia, khokhlach@mail.ru

Nekrasov Alexander Sergeyevich, Military Academy of RVSN named after Peter the Great, Balashikha, Russia, sanya.nekrasov.1992@mail.ru

Sidorov Nikolay Vladimirovich, Military Academy of RVSN named after Peter the Great, Balashikha, Russia, snv20072007@mail.ru

\begin{abstract}
Keywords: communication system stability, communication system object persistence, cost dependence, recovery intensity, numerical method algorithm, cost function
\end{abstract}

\begin{abstract}
In article discusses the problem of rational distribution of costs among the forces and means ensuring the preservation of the stability of the communication system. In the given task values of probability of reduction of stability of communication system and intensity of its recovery are determined. The article specifies the limitations of the task, as well as the stages of implementation. In the work, the function of costs for ensuring preservation of the required stability and the required intensity of its restoration is justified with determination of values and detection of trends of cost change at change of values of indicators of probability of reduction of stability of the communication system and intensity of its restoration. In the resulting result, the total cost of keeping the object alive is determined by the dependency resulting from the calculations. Areas of permissible values of variables of probability of reduction of stability of communication system and intensity of its recovery are determined. In the given task the algorithm of numerical method is defined, the result of which was formation of areas of permissible values of probability of reduction of stability of communication system and intensity of its restoration. The article described in detail the method of cost minimization, which was to determine the procedure of finding the required values, at which costs are minimized according to the task. Examples of determination of costs for object survival, required minimum values of survival function are given. The figures calculated in the computer program were tabulated. Dependencies were determined from the resulting values in the table. Based on the obtained schedules of cost dependence on survival, the corresponding conclusions were drawn.
\end{abstract}

Information about authors:

Filatov Vladimir Ivanovich, candidate of technical Sciences (KTN), associate Professor at the Bauman Moscow State Technical University, faculty of Informatics and control systems, Department of information protection, Moscow, Russia

Khokhlachev Yevgeny Nikolaevich, doctor of technical Sciences senior research associate of $t$ of he Military Academy of Strategic Rocket Troops after Peter the Great, 8 Karbyshev str., Balashikha, Moscow region, Russia

Nekrasov Alexander Sergeyevich, educator, research fellow of he Military Academy of Strategic Rocket Troops after Peter the Great, Balashikha, Russia

Sidorov Nikolay Vladimirovich, candidate of Military Sciences, Associate Professor, Military Academy of RVSN named after Peter the Great, Balashikha, Russia

Для цитирования:

Филатов В.И., Хохлачев Е.Н., Некрасов А.С., Сидоров Н.В.. Оценка и оптимизация затрат при обеспечении устойчивости системы связи // T-Comm: Телекоммуникации и транспорт. 2020. Том I4. №7. С. 57-63.

For citation:

Filatov V.I., Khokhlachev Y.N., Nekrasov A.S., Sidorov N.V. (2020) Expense evaluation and optimization for providing communication system sustainability. T-Comm, vol. 14, no.7, Pp. 57-63. (in Russian) 


\section{Formulating the task}

In the process of providing necessary sustainability for communication systems a task of reasonable expenditure distribution between sustainability providing means occurs. Indeed, a complex of expensive measures is necessary (such as extra service, increased protection etc) to reduce the probability of communication system falter, depending on its peculiarities [1]. However, even with high expenditures the chance of the system becoming non-sustainable can remain high, thus not meeting the necessary requirements. At the same time, if some part of the expenses is spent on operational sustainability restoring, this probability can be maintained at the necessary level.

Thus, we face an alternative: which part of expenses is to be spent on reducing sustainability decrease probability, and which part is to be spent on providing its restoring, so that the total expenditures are minimized, considering the given sustainability requirements.

The task can be formulated as follows. Such values of the probability of communication system sustainability decrease $P^{*}$ and its restoring intensity $\mu^{*}$ are to be defined, so that the smallest value of sustainability function $\varphi_{m}(P, \mu)$ is no less than the required $\left(\varphi_{\text {mтр }}\right)$ the value of total expenses $C(P, \mu)$ being minimal, i. e.

$$
\begin{aligned}
& \mathrm{C}\left(P^{*}, \mu^{*}\right)=\min _{P, \mu}\left[C_{Z}(P)+C_{v}(\mu)\right], \varphi_{m}(P . \mu) \geq \varphi_{m \tau p}, \\
& 0 \leq P \leq 1, \mu>0
\end{aligned}
$$

where $C_{z}(P)$ and $C_{v}(\mu)$ are expenses for maintaining the required sustainability and the necessary intensity of its restoring respectively.

This task is a non-linear programming task [2] and has the following constraints and specific features:

No uniquely determined functions $C_{z}(P)$ и $C_{v}(\mu)$, whose feasibility requires extra apriori data for correlation of expenses to $P$ and $\mu$ values;

Analytical expressions for the sustainability function $\varphi_{m}(P$, $\mu$ ), particularly for the large number of attacks, are quite complicated, thus, using those expressions explicitly is impractical;

Determination and analysis of the allowed set of values $P$ and $\mu$, meeting inequations $\varphi_{m}(P, \mu) \geq \varphi_{\text {mтр }}, 0 \leq P \leq 1, \mu>0$, deals with working out new effective algorithms and computer programs

Taking into account these features, the procedure of working out an acceptable method for solving the task includes the following stages:

Reasoning the general approach to formulating functions $(P)$ and $C_{v}(\mu)$ based on the analysis of resources spent for providing communication system sustainability;

Formulating and analysis of the allowed set of values $\boldsymbol{D}$ for variables $P$ and $\mu$, limited by the function $\varphi_{m}(P, \mu)=\varphi_{\text {ттр }}$;

Choosing the most effective method of solving the non-linear programming task, taking into account the peculiarities of the objective function $C\left(P^{*}, \mu^{*}\right)$ and constraints;

Working out the algorithm and computer programs for the method and its efficiency and accuracy evaluation;

Method probation for the particular example of determining reasonable expenses, providing the required workability of the communication system.
Methods of solving such a task were examined in detail in [3-6] applicable to certain communication systems and satellite guidance systems. The article demonstrates the results of the analysis and generalization of these methods for their prospective use in reasoning communication system sustainability requirements.

\section{Expense function}

Feasibility of functions $C_{z}(P)$ and $C_{v}(\mu)$ is connected with determining their allowed set of values and finding the tendency of expense changes with $P$ and $\mu$ value changes.

Obviously, whatever great expenses, sustainability $P=0$ cannot be provided by a complex attack on the system. Therefore $C_{\mathrm{z}}(P=0) \rightarrow \infty$. At the same time, there is a tendency of rapid expense growth with $P$, value, close to 0 . It can also be suggested that with no expenses and rejecting sustainability maintaining activities probability will be close to one, which means $C_{z}(P=1)$ $=0$. However, the rate of expense change with $P$, values close to one remains very low. Such extreme values and tendencies of expense change correspond to the following logarithmic function:

$$
C_{\mathrm{z}}(P)=-k_{\mathrm{z}} \ln P
$$

where $k_{z}$ is the protection rate taking into account expense change per $\ln P$; «-» sign used because of $\ln P \leq 0$.

One of the possible variations of $C_{z}(P)$ function graph is illustrated in figure $1 \mathrm{a}$.

Intensity $\mu$ is a value, reciprocal to the average time of communication system element $m_{\tau}$, restoring i. e. $\mu=1 / m_{\tau}$. Determining correlation between restoring expenses and restoring time, the following algorithm can be suggested. Suppose an object includes $n$ damaged blocks (details, aggregates etc). The average restoring time for each block equals $m_{\tau \tilde{\tau}}$. Staff is organized for restoring operations with necessary equipment, organizational expenses equaling $C_{\bar{\sigma}}$. The staff can restore blocks one after another. Therefore, total object restoring time equals $m_{\tau}=$ $n m_{\tau \curvearrowleft}$, and restoring expenses equal $C_{v}=C_{\bar{\sigma}}$.

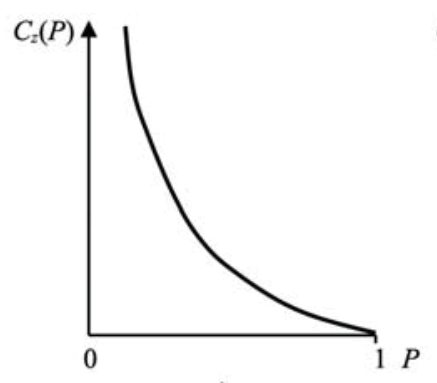

a)

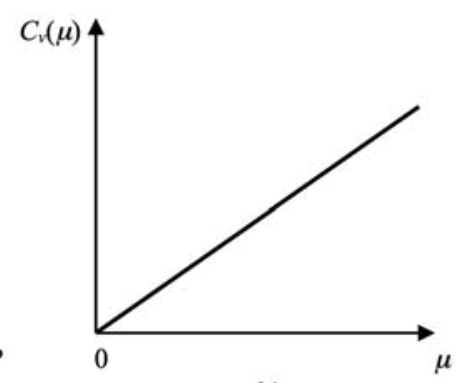

b)
Fig. 1. Expense correlation with $P$ and $\mu$ values

Suppose we now organize two staff units, organizing expenses equaling $C_{v}=2 C_{5}$. These units can simultaneously restore two blocks, total restoring time reducing by half and equaling $m_{\tau}=2^{-1} n m_{\tau \sigma}$. Organizing three units of staff, we have the following data: 
$C_{v}=3 C_{\tilde{\sigma}}, m_{\tau}=3^{-1} n m_{\tau \sigma}$.

Organizing $n$ units of staff

$C_{v}=n C_{\sigma}$ and $m_{\tau}=n^{-1} n m_{\tau \sigma}=m_{\tau \sigma}$.

As a result, the product $C_{v} m_{\tau}$ will be a constant value, provided average values $_{\tau \sigma}, C_{\sigma}$ and $n$ remain fixed, i.e. $C_{v} m_{\tau}=n C_{\sigma} m_{\tau \sigma}=k_{v}$.

Thus, according to the current research scheme, we have $C_{v}$ reciprocally dependent on $m_{\tau}, C=k_{v} / m_{\tau}$. If we now replace $m_{\tau}$ with $1 / \mu$, we find the expense dependence on restoring intensity:

$$
C_{v}(\mu)=k_{v} \mu
$$

where $k_{v}$ is the restoring rate or expense change per $\mu$.

One of the possible $C_{v}(\mu)$ function graphs is illustrated in Figure 1b.

As a result, total expenses for providing object viability can be determined by the following formula:

$C(P, \mu)=k_{\mathrm{v}} \mu-k_{\mathrm{z}} \ln P$

\section{Determination algorithm for the set of allowed values}

Formulating set $\boldsymbol{D}$ of allowed values for variables $P$ and $\mu$, limited by the correlation $\varphi_{m}(P, \mu)=\varphi_{\text {mтр }}$, is only possible with using numerical methods due to implicit assignment of the transcendental function $\varphi_{m}(P, \mu)$. Numerical method's general algorithm includes the following stages:

1. I roducing the given data: $\lambda$ - enemy's attack intensity, $n$ - upposed number of attacks, $\varphi_{\text {ттр }}-$ viability function minimal required value.

2. $\quad$ signing a cycle formulating values $P_{i}$. Normally $P$ is formulated with an accuracy within $1 \%$, i. e. $P=0,01 ; 0,02 ; \ldots ; 1$.

3. Assigning the cycl to formulate values $\mu_{j}=0,01 ; 0,02 ; \ldots$; $\mu_{\max }$, where $\mu_{\max }$ choice is based on experience. Normally $10 \leq \mu_{\max } \leq 30$.

4. As gning the cycle to formulate values $t_{k}=0 ; 0,1 ; 0,2 ; \ldots$; $t_{\max }$, where $t_{\max }$ choice is based on the supposed duration of the warfare or object functioning.

5. D ermining balues of the function $\varphi\left(P_{i}, \mu_{j}, t_{k}, \lambda, n\right)$ with the use of the following correlations [140]:

$$
\begin{aligned}
& \varphi(t, 1)=1-P F_{1} ; F_{1}=\lambda(\mu-\lambda)^{-1}\left(\mathrm{e}^{-\lambda t}-\mathrm{e}^{-\mu t}\right) ; \\
& \varphi(t, 2)=1-P\left[F_{1}+(1-P) F_{2}\right]-P^{2} F_{4} ; \\
& \varphi(t, 3)=1-P\left[F_{1}+(1-P) F_{2}+(1-P)^{2} F_{3}\right]-P^{2}\left[F_{4}+\right. \\
& \left.+2(1-P) F_{5}\right]--P^{3} F_{6},
\end{aligned}
$$

where $\varphi(t, n)$ - is object viability function for $n$ enemy's attacks; $F_{i}$ - expressions determined by the resultants of the function of time distribution probability between attacks $F(t)$ and restoring time $G(t)$.

6. omparing values $\varphi\left(P_{i}, \mu_{j}, t_{k}\right)$ for fixed $P_{i}, \mu_{j}$ and the variable $t_{k}$. Determining function $\varphi_{m}\left(P_{i}, \mu_{j}\right)$ minimal value.

7. ormulating remainders $\Delta_{j}=\left|\varphi_{m}\left(P_{i}, \mu_{j}\right)-\varphi_{\text {mтр }}\right|$ with fixed $P_{i}$ and variable $\mu_{j}$. Finding the remainder $\Delta_{j}$, corresponding to the inequation $\Delta_{j} \leq 0,001$. This inequation provides high precision of the numerical method, i. e. Corresponding of $\varphi_{m}\left(P_{i}, \mu_{j}\right)$ to $\varphi_{\text {ттр }}$ within $0,1 \%$.

8. xing $P_{i}$ and $\mu_{j}$, corresponding to the remainder $\Delta_{j} \leq 0,001$, and formulating the set of values $P_{i}$ and the set of corresponding values $\mu_{j}$, with $\varphi_{m}\left(P_{i}, \mu_{j}\right)=\varphi_{m \text { тр }}$ within a given accuracy.

9. Filling in the table with the set of values $P_{i}$ and $\mu_{j}$ and building $\mu=f(P)$ function graph at $\varphi_{m}(P, \mu)=\varphi_{m т р}$.

In figure 3.2 allowed sets of values $\boldsymbol{D}$ are illustrated, limited by functions $\varphi_{m}(P, \mu)=0,9$, at $n=1,2,3 ; \lambda=1$, and lines $P=0$ and $P=1$. The shaded $\boldsymbol{D}$ area is that limited by the function at $n=3$.

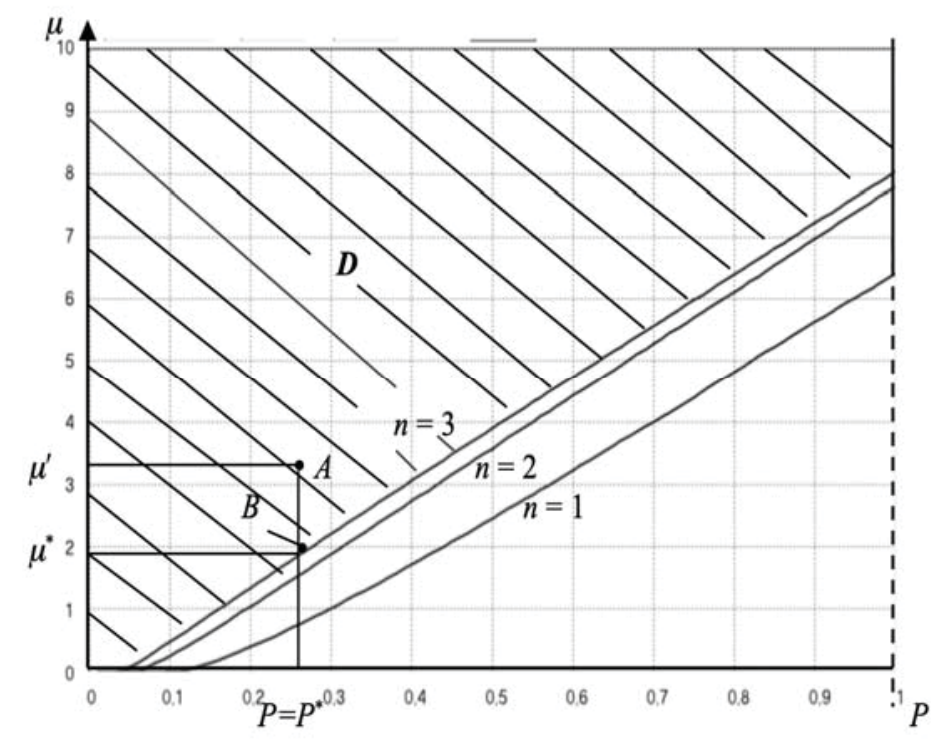

Fig. 2. Formulating sets of allowed values $P$ and $\mu$ at $\varphi_{\text {mтр }}=0,9 ; \lambda=1$ and $n=1,2,3$

The graphs show that sets $\boldsymbol{D}$ of allowed values for variables $P$ and $\mu$, restrained by (1), are convex. For any poin $A\left(P^{\prime}, \mu^{\prime}\right)$ lying within these sets of values, there is a point $B\left(P^{*}, \mu^{*}\right)$ at the border of the areas $\varphi_{m}(P, \mu)=\varphi_{\text {mтр }}$ for which $C\left(P^{*}, \mu^{*}\right)<<<<$ $C\left(P^{\prime}, \mu^{\prime}\right)$. Indeed, if any point $A\left(P^{\prime}, \mu^{\prime}\right)$ is taken (see figure 3.2), it always corresponds to a certain point $B\left(P^{*}, \mu^{*}\right)$, for which $\mu^{*}$ $<\mu^{\prime}$ at $P^{*}=P^{\prime}$. Since the expense function (3.4) is proportional to values $P$ and $\mu, C\left(P^{*}, \mu^{*}\right)<C\left(P^{\prime}, \mu^{\prime}\right)$. Based on that, a conclusion can be drawn that the expense function minimum according to the mission assigned is to be sought at the lower limit of $\boldsymbol{D}$ set of values, thus the inequation (1) can be replaced with the equation $\varphi_{m}(P, \mu)=\varphi_{\text {ттр }}$.

Figure 3 illustrates other variants of allowed sets of values limited by the functions $\varphi_{m}(P, \mu)=0,9$, at $n=1$ and $\lambda=1,2,3$.

The shaded area $\boldsymbol{D}$ is limited by the function at $\lambda=3$. Similar arguments are applicable for finding the expense function minimum at the lower limit of the $\boldsymbol{D}$ area.

\section{4. thod of expense minimization}

The results achieved determine the procedure of finding the required values $P^{*}$ and $\mu^{*}$, for which expenses are minimal according to the assigned task (1). 


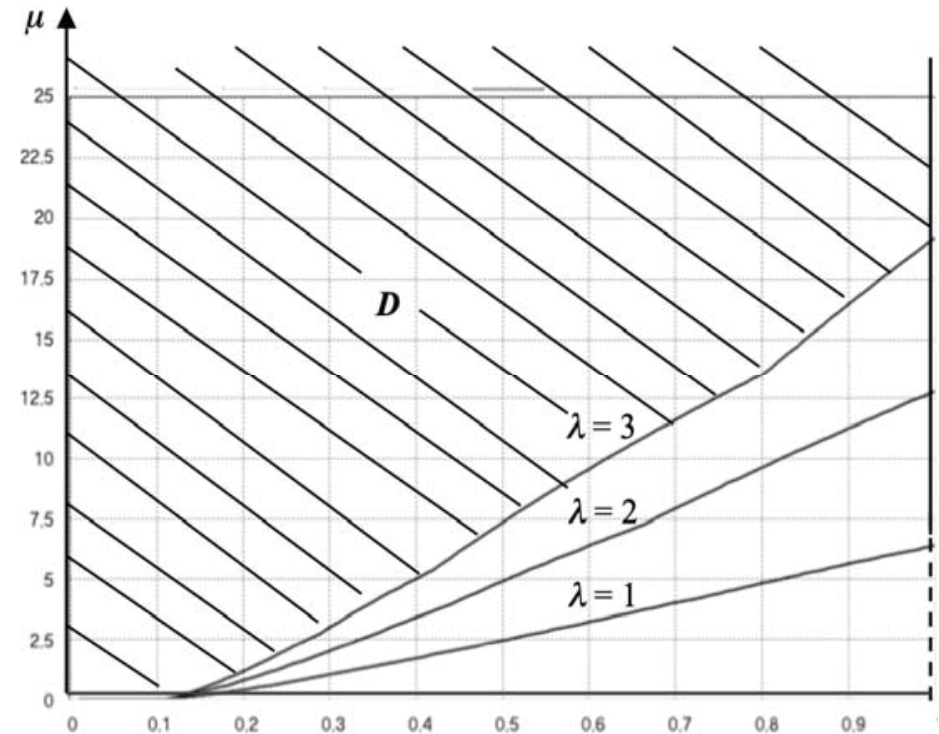

Fig. 3. Formulating allowed sets of values $P$ and $\mu$ at $\varphi_{\text {ттр }}=0,9 ; n=1$ and $\lambda=1,2,3$

To achieve the claimed goal, any of the suggested methods of non-linear programing task solving with non-linear function and limitations can be chosen [7-8]. However, taking into consideration the small amount of variables (only two), the method of targeted search can be used for the solution [9].

The method is the following:

Based on the given data $\lambda, n$ и $\varphi_{\text {ттр }}$ the set of allowed values $\boldsymbol{D}$ is determined for variables $P$ and $\mu$;

A growing expense succession is formulated $C_{i}, i=0,1,2, \ldots$, starting with the minimal possible value $C_{0} ; \Delta_{i}=C_{i+1}-C_{i}$ is chosen according to the required precision of calculating;

Coefficients $k_{v}$ и $k_{z}$ are given and values $P_{i}$ и $\mu_{i}$,corresponding to the following equations are determined succeedingly:

$$
k_{v} \mu_{i}-k_{z} \ln P_{i}=C_{i} ; i=0,1,2, \ldots ;
$$

acquired values $P_{i}$ и $\mu_{i}$ are compared to the values of $P$ and $\mu$ coordinates for the point of the lower limit in the set of values $\boldsymbol{D}$ within the required precision.

At a certain $n$ comparison level $(i=n)$ tangency point is determined $B\left(P^{*}, \mu^{*}\right)$ for the curve $\varphi_{m}(P, \mu)=\varphi_{\text {ттр }}$ and the curve $C(P, \mu)=C_{n}$, whose coordinates $P^{*}$ and $\mu^{*}$ determine the required solution.

Figure 3.4 demonstrates a variant of such graphic solution of the task for the following data: $\lambda=1 ; n=1 ; \varphi_{\text {mтр }}==0,9 ; k_{v}=1$; $k_{z}=2$.

Tangency point for the curve determined by the equation $3,385=\mu+2 \ln P$, has the following coordinates $P^{*} \approx 0,3 ; \mu^{*} \approx 1$. Consequently, minimal expenses $C_{\min }$ for providing object viability for the value of 3,385 cost units, the recommended protection expenses being $C_{z}=2,385$ cost units.

Compared to the graphic method, the numerical method gives more precise results [10]. For example, for the data given above, we acquire the following results $P^{*}=0,29 ; \mu^{*} \approx 0,94, C_{\min }=$ $3,41, C_{v}=0,94, C_{z}=2,47$.

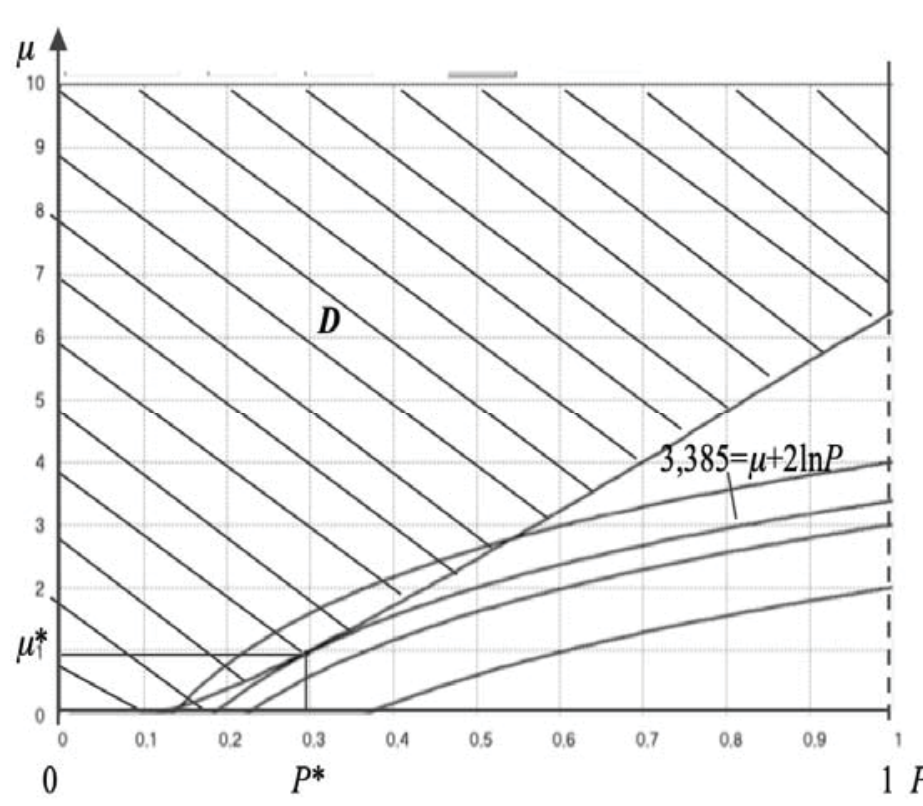

Fig. 4. Possible graphic solution of the task

\section{5. xpense determining examples and results}

The suggested method allows to achieve practical suggestions in rational resource distribution while providing the required communication system viability [11]. However, for the results to be trustworthy, the following steps are required.

Firstly, reasoning and applying the method of foreseeing possible consequences of enemy's attack on the communication system to determine the number of attacks, time intervals and object destruction probability.

Secondly, specifying the dependence (1) of total viability providing expenditures on its restoring possibility and protectability, based on reviewing statistics [12]. Both coefficient values $k_{v}$ and $k_{z}$, and the type of functions used are to be considered.

Example 1. Let us determine minimal costs of communication system viability providing for the following given data:

Attack intensity $\lambda=1[1 /$ day], i. e. an average of one attack a day is expected; expected number of attacks $n=3$;

The required minimal value of the viability function $\varphi_{\text {mтр }}=0,9$, i. e.accurate communication system functioning probability for the whole period of warfare is required to be no less than 0,9 ;

$k_{v}=2$ mln roubles per restoring intensity unit $\mu$ is given for restoring the object viability, i. e., to provide $\mu=1$ [1/day] or $m_{\tau}=1$ day 2 mln roubles is required., for $\mu=2[1 /$ cyday] or $m_{\tau}=12 \mathrm{~h} 4 \mathrm{mln}$ roubles is required etc;

$k_{\mathrm{z}}=3 \mathrm{mln}$ roubles per negative unit $\ln P$ is given for providing protection, i. e., for providing $\ln P=-1$ or $P \approx 0,373 \mathrm{mln}$ roubles is required, for $\ln P=-2$ or $\mathrm{P} \approx 0,136 \mathrm{mln}$ roubles is required., finally, to provide practically absolute protection, where $\ln P=-10$ and $P \approx 0,000045,30 \mathrm{mln}$ roubles is required

For solving the task we shall use the computer program (see part 3.6), which after input of all the given data gives the following results $\mu^{*}=1,08 \approx 1\left[1 /\right.$ day]; $P^{*}==0,17 ; C_{\min }=7,47 \mathrm{mln}$ roubles. 
Thus, to provide the required viability it is enough to spend $7,47 \mathrm{mln}$ roubles and restoring activities should be organized ensuring restoring intensity 1,08[1/day] or average restoring time $m_{\tau} \approx 1$ day, and attack intensity 0,17 , which leads to the following expenditure decrease: restoring expenditure $-2,16 \mathrm{mln}$ roubles., protection expenditure $-5,31 \mathrm{mln}$ roubles

Graphic solution of the task is illustrated in figure 5.

Based on the graph built we have the following approximate results:

$$
\mu^{*} \approx 1[1 / \text { day }] \text { и } P^{*}=0,17
$$

which mostly correspond to the data described above.

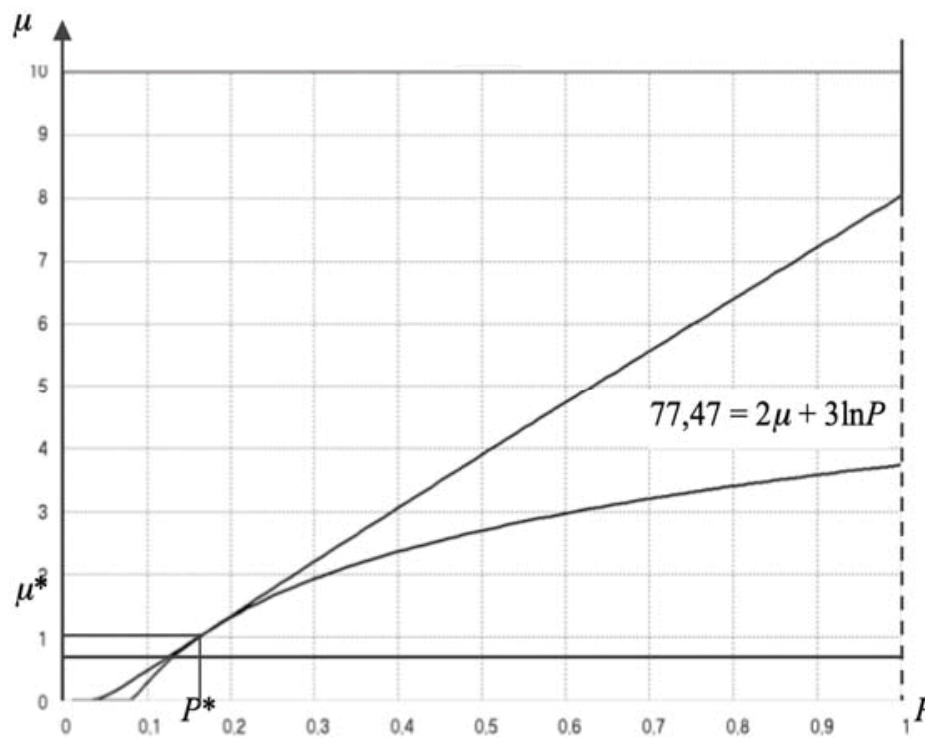

Fig. 5. Graphical solution for example 1

Example 2. Enemy attack intensity $\lambda=1$, expected number of attacks $n=3$, principal expenses $k_{v}=2, k_{z}=3$. The task is to find the dependence of communication system viability providing expense from the required maximal viability function value.

Let us set the required minimal values for viability function $\varphi_{\text {mтр }}=0 ; 0,1 ; 0,2 ; \ldots ; 0,9 ; 0,91 ; \ldots ; 0,99 ; 1$. For each value we use a computer program (see part 6) to fins the minimal required expense. Table 1 gives the calculation results.

\section{Expense calculation results}

Table 1

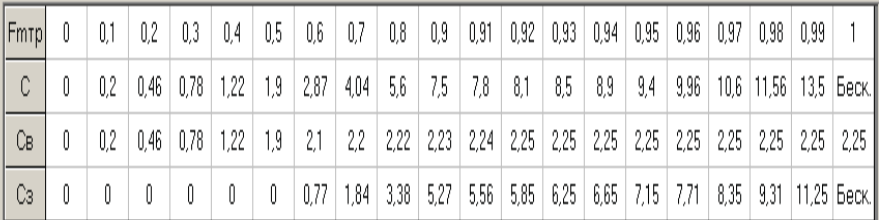

Line 1 includes values $F_{\text {ттр }}=\varphi_{\text {ттр }}$, line 2 shows total expense values $C$ for providing viability, line 3 shows restoring expense values $C_{\mathrm{B}}=C_{v}$, line 4 shows object protection values $C_{3}=C_{z}$

Based on the acquired results, dependence graphs $C\left(\varphi_{\text {ттр }}\right)$, $C_{v}\left(\varphi_{\text {ттр }}\right)$ и $C_{z}\left(\varphi_{\text {ттр }}\right)$ are built, shown in figure 6.

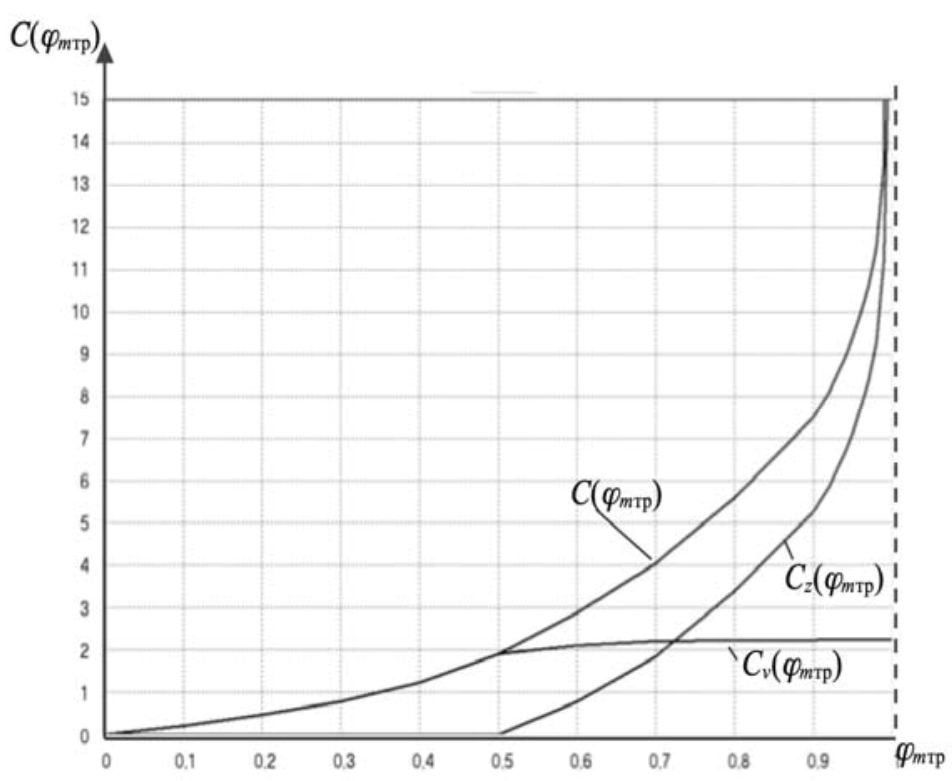

Fig. 6. Dependence of cost on viability

Analysis of these graphs demonstrates that since low requirements are set for communication system viability, where $\varphi_{\text {mтр }}<0,5$, it is only feasible to spend resources on communication system restoring. Meanwhile, protection costs equal 0 , and as additional calculations show, object destruction probability $P^{*}=1$.

If higher viability requirements are claimed, where $\varphi_{\text {mтр }} \geq 0,5$, system protection costs $C_{z}\left(\varphi_{\text {mтр }}\right)$ are growing steadily, whereas restoring costs $C_{v}\left(\varphi_{\text {ттр }}\right)$ are stabilized and this value becomes constant whatever viability requirements are.

Thus, based on the calculations the following conclusion can be made: to minimize total expense in conditions of increasingly high viability requirements, rational constant system restoring expenses are to be determined and the reasons for increasing protection expense graph are to be provided.

\section{References}

1. Anpilogov V.R. (2015). "Efficiency of low-orbit satellite communication systems on the basis of small spacecrafts," Technologies and means of communication. No. 4. P. 62-66.

2. Communication systems on the basis of not geostationary satellites of KA range. (2009). Technologies and means of communication. No. 6-2. Special release "Satellite communication and broadcasting 2010". Under the general editorial office Anpilogov V.R. P. 42-43.

3. Chernov A.A., Chernavsky G.M. (2004). "Orbits of satellites of remote sensing of Earth. Lectures and exercises," Moscow: Prod. Radio and communication. 
4. Cantor L. Ya., Heifetz of V.N.

(2001).

"Kvazigeostatsionarnaya orbit," Telecommunication. No. 4.

5. Wind B.B., Gritsenko A.A. Sistema of satellites in elliptic orbits emulating features of the system of satellites on a geostationary earth orbit. Patent of the Russian Federation No. 2223205. Request of 28.03.2002.

6. Wind B.B., Lipatov A.A., Gritsenko A.A., etc. (2001). "Virtual and pseudo-stationary orbits in regional satellite communication systems and broadcastings," Technologies and means of communication. No. 5.

7. Testoyedov N.A., Vygonsky Yu.G., Kuzovnikov A.V. (2015). "The domestic system of personal mobile satellite communication with spacecrafts on a geostationary and high-elliptic earth orbit," High technologies. Vol. 16. No. 3.

8. RD 45.041-99. Norms on electric parameters of digital channels and paths of satellite transmission systems. It is approved by the Order of Gostelekom of Russia of September 28, 1999 No. 48.
9. Tsimbal M., Panko S. (2015). Features of the HEO Satellite Communication Systems, International Siberian Conference on Control and Communications.

10. Shalaginov A. (2014). "Projects of multifunction satellite systems for the Arctic regions of Russia," Technologies and means of communication. No. 6(2). Special release "Satellite communication and broadcasting - 2014". P. 16-17.

11. Lokshin B. (2013). "About one possibility of the organization of mobile communication with VEO in Ku-diapazone," Technologies and means of communication. No. 6(2). Special release "Satellite communication and broadcasting - 2014". P. 18-20.

12. Anpilogov V. (2013). "About problems of satellite communication and broadcasting in the Arctic," Technologies and means of communication. No. 6(2). Special release "Satellite communication and broadcasting - 2014". P. 24-31. 


\section{ОЦЕНКА И ОПТИМИЗАЦИЯ ЗАТРАТ ПРИ ОБЕСПЕЧЕНИИ УСТОЙЧИВОСТИ СИСТЕМЫ СВЯЗИ}

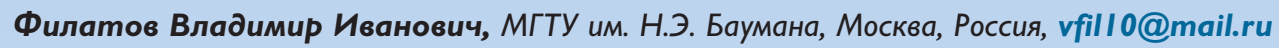

Хохлачев Евгений Николаевич, ВА РВСН им. Петра Великого, Московская область, Балашиха, Poccuя, khokhlach@mail.ru Некрасов Александр Сергеевич, Военная академия РВСН им. Петра Великого, г. Балашиха, Россия, sanya.nekrasov.1992@mail.ru

Cидоров Николай Владимирович, Военная академия РВСН им. Петра Великого, г. Балашиха, Россия, snv20072007@mail.ru

\section{Аннотация}

Рассмотрена задача рационального распределения затрат между силами и средствами, обеспечивающими сохранение устойчивости системы связи. В поставленной задаче определяются значения вероятности снижения устойчивости системы связи и интенсивности ее восстановления. В статье указаны ограничения поставленной задачи, также указаны этапы реализации. В работе обоснована функция затрат на обеспечение сохранения требуемой устойчивости и необходимой интенсивности ее восстановления с определением значений и выявлением тенденций изменения затрат при изменении значений показателей вероятности снижения устойчивости системы связи и интенсивности ее восстановления. В полученном результате суммарные затраты на обеспечение живучести объекта определены зависимостью, полученной в результате вычислений. Определены области допустимых значений переменных вероятности снижения устойчивости системы связи и интенсивности ее восстановления. В поставленной задаче определен алгоритм численного метода, результатом которого было формирование областей допустимых значений вероятности снижения устойчивости системы связи и интенсивности ее восстановления. Подробно раскрыт метод минимизации затрат, который заключался в определении процедуру поиска требуемых значений, при которых минимизируются затраты в соответствии с поставленной задачей. Приведены примеры определения затрат на обеспечение живучести объекта, требуемого наименьшего значения функции живучести. Показатели, рассчитанные в компьютерной программе, были сведены в таблицу. По результатам полученных значений в таблице были определены зависимости. По полученным графикам зависимости стоимости от живучести, были сделаны соответствующие выводы.

Ключевые слова: устойчивость системы связи, живучесть объекта системы связи, зависимость затрат, интенсивность восстановления, алгоритм численного метода, функция затрат.

\section{Литература}

І. Карвовский Г.С. Методы исследования систем связи и АСУ. М.: МО СССР, 1986.

2. Липский В. Комбинаторика для программистов. М.: Мир, 1988.

3. Хохлачев Е.Н. Организация и технологии выработки решений при управлении системой и войсками связи. Часть 2. Выработка решений при восстановлении сетей связи. М.: РВСН, 2009.

4. Хохлачев Е.Н., Перекрестов С.А., Новикова Е.Е. Программа прогнозирования критических ситуаций и минимизации затрат при обеспечении живучести объектов. Свидетельство о государственной регистрации программ для ЭВМ №20166II663 от 09 февраля 2016 года. М.: Роспатент, 2016.

5. Хохлачев Е.Н. Оптимизация затрат при обеспечении живучести наземных объектов системы управления спутниками. Вестник ФГУП "НПО им. С.А. Лавочкина". №l. 2010.

6. Khokhlachev E.N. Cost Optimization for Maintaining the Survivability of Terrestrial Objects of a Satellite Control System. MAIK "Nauka/Interperiodica", vol. 45, No. 7, 201 I.

7. Беркетов Г.А., Блаженков В.В., Кравеи, Л.И., Оселедеи В.И. Современные математичские методы анализа и синтеза сложных систем. М.: МО СССР, 1984.

8. Хедли Дж. Нелинейное и динамическое программирование. М.: Мир, 1967.

9. Крушевский А.В. Теория игр. Киев: Вища школа, 1977.

І О. Дунин-Барковский И.В., Смирнов Н.В. Теория вероятнойстей и математическая статистика в технике. М.: Гостехиздат, 1955.

І І. Дудник Б.Я., Овчаренко В.Ф., Орлов В.К. и др. / Под. ред. Дудника Б.Я. Надежность и живучесть систем связи. М.: Радио и связь, 1984.

12. Кофман А. Введение в прикладную комбинаторику. М.: Наука, 1975.

\section{Информация об авторах:}

Филатов Владимир Иванович, к.т.н., доцент кафедры МГтУ им. Н.Э. Баумана факультета "Информатика и системы управления", кафедры "Защита информации", Москва, Россия

Хохлачев Евгений Николаевич, д.т.н., старший научный сотрудник ВА РВСН им. Петра Великого, Московская область, Балашиха, Россия Некрасов Александр Сергеевич, преподаватель, научный сотрудник, Военная академия РВСН им. Петра Великого, Московская область, 2. Балашиха, Россия

Сидоров Николай Владимирович, кандидат военных наук, доцент, Военная академия РВСН им. Петра Великого, Московская область,

2. Балашиха, Россия 